\title{
極低降伏点鋼 LY100を用いた多段スリット入り鋼板耐震壁の開発 DEVELOPMENT OF MULTI-ROW SLIT SHEAR WALLS USING LOW YIELD POINT STEEL
}

\author{
東郷拓真*, 和 留生*, 林 和宏**, 倉田真 宏***, 中島 正 愛**** \\ Takuma TOGO, Liusheng HE, Kazuhiro HAYASHI, \\ Masahiro KURATA and Masayoshi NAKASHIMA
}

\begin{abstract}
The steel slit shear wall, in which stiffness and strength are controlled by altering the length, interval and pattern of slits, has been studied as an earthquake-resisting element with high energy dissipation capacity. Local buckling in each link (the segment between slits) and strength degradation that would cause reduction of energy dissipation capacity can be restrained by increasing the number of slit rows with keeping the strength and stiffness constant. This paper proposes the use of low yield point steel (LY100) for the steel slit shear wall. Expansion of plasticity caused by the significant strain hardening of LY100 makes shear deformation distribution more equal in each slit row and disperses the strain concentrated in the edge of links. Furthermore, the larger maximum rupture strain of LY100 than that of conventional steel reduces the risk of fracture at the edge of link. The advantages of the proposed steel slit shear wall are demonstrated by both the test and analysis.
\end{abstract}

Keywords : Steel slit shear wall, Low yield point steel, Width-thickness ratio, Shear deformation distribution スリット入り鋼板而震壁, 低降伏点鋼, 幅厚比，せん断変形分布

\section{1. はじめに}

耐震部材の一つであるスリット入り鋼板耐震壁 ${ }^{1) 6}$ は、図 1(a)に 示すように、建物骨組の上下梁に剛接合した鋼板に多数のスリット を鉛直方向に配したもので、スリットで挟まれた部分（以下ではこ れを柱状部と呼ぶ）が柱のように曲げ挙動を示し、安定した塑性変 形能力が期待できる（図 1(b)参照）。

スリット入り鋼板耐震壁はスリットの本数や長さを調整すること で剛性および耐力を自在に調整できるため、既往の座屈拘束ブレー スやスチフナ付き鋼板耐震壁に比べて、配置する建物の耐震性能要 求に対して、剛性と耐力の両面から最適な設計を行うことが容易で ある。またその製作においても、平板にレーザー加工によるスリッ トを設けるだけでよく、面外補剛等の取り付けに伴う溶接加工を要 しないという、施工の簡便性や運搬性を有している。しかし既往の 研究 ${ }^{1}$ によれば、柱状部の幅厚比が一定值を超えると大変形におい て耐力劣化やスリット端周辺に局部座屈が発生し、エネルギー消費 性能が低下寸る。この耐力劣化や局部座屈を防ぐためには、スリッ 卜の段数（図 1 の例では 2 段）を増やすという方法が考えられる。 これは、スリットの段数を増やすことで、スリット入り鋼板が耐震 壁としての耐力と剛性を維持しつつ幅厚比を小さくすることができ
るためである。ただし、鋁直方向に段数を増やした場合、図 1(b) の ように各段スリットのせん断変形が均等にならず、図 1(c)のように 特定の段にのみ変形が集中し、耐震壁としてのエネルギー消費性能 が低下寸る恐れがある。

そこで本研究では、各段のスリットに対してより均等なせん断変 形を確保するため、鋼板に極低降伏点鋼 ${ }^{77-9)}$ LY100 を適用する。こ の極低降伏点鋼 LY100 は、普通鋼に比べ顕著な等方硬化成分 ${ }^{7)}$ を有 しており、鋼材が降伏し塑性ひずみを経験することで、見かけの降 伏応力（以下、等価降伏応力）が上昇する。従って、スリット入り 鋼板の特定の段に塑性変形（ひずみ）が集中し始めた場合でも、等
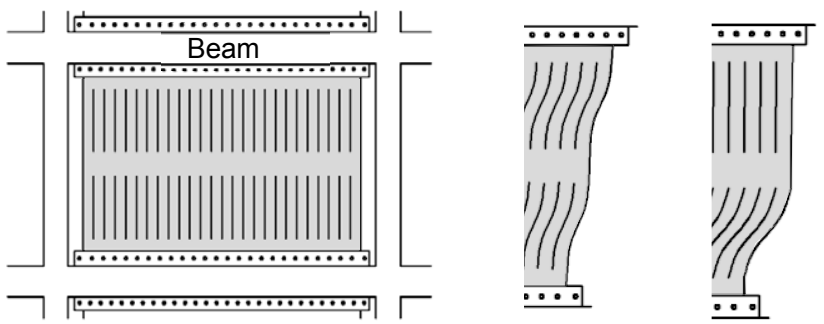

(a) Slit shear wall in frame

(b) Deformation

(c) Concentration of deformation

\footnotetext{
* 京都大学大学院工学研究科 大学院生

** 豊橋技術科学大学大学院工学研究科 助教 - 博士 (工学)

*** 京都大学防災研究所 准教授 $\cdot$ Ph. D.

**** 京都大学防災研究所 教授. Ph. D.
}

Graduate Student, Faculty of Engineering, Kyoto Univ. Assistant Prof., Graduate School of Engineering, TUT, Dr. Eng. Assoc. Prof., DPRI, Kyoto Univ., Ph. D.

Prof., DPRI, Kyoto Univ., Ph. D. 
価降伏応力の上昇に伴ってその段の柱状部耐力も増大する。その結 果、更なる荷重増分に対しては、相対的に耐力が小さくなった特定 段以外の段に塑性変形が分配されるため、結果としてせん断変形が 鋼板全体で均一となることが期待できる。

また、耐震設計においては、主架構の損傷はできるだけ抑えつつ、 耐震要素の地震エネルギー消費を促進するため、耐震壁を周辺骨組 に先行して降伏させる「早期降伏」が効果的である $\left.{ }^{10)}, 11\right)$ 。 しし、 早期降伏を想定した耐震要素では、極大地震下の大変形下では塑性 率が一層増すので、高い塑性変形能力が要求される。既往の研究 ${ }^{5)}$ は、普通鋼を用いたスリット入り鋼板（それほどの早期降伏は想定 していないモデル）の準静的載荷実験において、塑性化の進展に伴 ってスリット端部に応力とひずみが集中し、層間変形角 $2 \%$ 程度で 鋼板に亀裂が発生することを確認している。本研究が用いる極低降 伏点鋼は、普通鋼に対して 2 倍程度と高い破断伸び能力を有する靭 性材料である。さらに、極低降伏点鋼の等方硬化成分によって、ス リット端部の塑性化進展に伴い等価降伏応力が上昇し、塑性ひずみ がスリット端からその周辺に分散され、亀裂の発生を抑止すること も期待できる。

本論では、極低降伏点鋼 LY100 を用いたスリット入り鋼板耐震壁 試験体と、普通鋼 SS400 用いた試験体を製作し、準静的載荷実験 からその塑性変形性状、特に各段のせん断変形量の分布とスリット 端亀裂発生の有無を比較する。また、極低降伏点鋼試験体では、ス リット段数を変数とし、柱状部の幅厚比がエネルギー消費性能に与 える影響を検証する。

\section{2. スリット入り鋼板の設計}

本論では、スリット入り鋼板耐震壁の荷重 - 変形関係をトリリニ アモデルと近似した上で、その設計手順を示す。図 2 に示すように、 柱状部の曲げ変形が支配的であるスリット入り鋼板全体の水平剛性 $K$ 、弾性限耐力 $Q_{y}$ および全塑性耐力 $Q_{u}$ は、次式で近似できる ${ }^{1)}$

$$
\begin{aligned}
K & =\frac{1}{\frac{\kappa H}{G B t}+\frac{H \alpha^{2} \beta}{E B t}\left(1+\frac{1}{\alpha}\right)^{3}} \\
Q_{y} & =\frac{t B}{3 \alpha} \cdot \sigma_{y} \\
Q_{u} & =\frac{3}{2} \cdot Q_{y}
\end{aligned}
$$

ここで、 $E$ : 鋼材のヤング係数、 $G$ : 鋼材のせん断弾性係数、 $\sigma_{y}:$ 鋼材の降伏応力、 $\kappa$ : 形状係数、 $B$ : 鋼板の幅、 $H$ : 接合部を除いた 鋼板の高さ、 $t:$ 鋼板の厚さである。

$\alpha$ は柱状部のアスペクト比、 $\beta$ は柱状部の延べ高さが鋼板高さ $H$ に占める割合を表す。

$$
\begin{aligned}
& \alpha=\frac{l}{b} \\
& \beta=\frac{m l}{H}
\end{aligned}
$$

ここで、 $m:$ スリット段数 (図 2 の例では 2 段)、 $l$ : 柱状部の高さ、 $b:$ 柱状部の幅である。

弾性限耐力 $Q_{y}$ に到達する時の鋼板の変形量は、次式で表される。

$$
\delta_{y}=\frac{Q_{y}}{K}
$$

スリット入り鋼板耐震壁の耐力劣化や柱状部における局部座屈は、 柱状部の幅厚比 $b / t$ を閾值 $\gamma$ 以下とすることで抑止できる ${ }^{1)}$ 。ここで、 式(4)と式(5)から、柱状部の幅厚比 $b / t$ について式(7)が得られる。

$$
\frac{b}{t}=\frac{H \beta}{\alpha t m} \leq \gamma
$$

式(7)の右辺では、スリット段数 $m$ 以外の值を定数とすれば、スリ ット段数 $m$ と幅厚比 $b / t$ は反比例の関係にある。エネルギー消費性 能の低下は幅厚比が大きいほど顕著になるため ${ }^{1)}$ 、耐震壁としての 剛性と耐力を維持しつつ、幅厚比を下げ耐力劣化や柱状部の局部座 屈を抑えるには、式(7)を満たすよう段数 $m$ を設計すればよい。

さらに、スリット入り鋼板の壁部（鋼板におけるスリットの入っ ていない部分で、図 2 におけるWall を指す）については、鋼板が 安定してせん断変形するよう ${ }^{12}$ 、柱状部一柱状部間は $b$ 以上、柱状 部一接合部間は $0.5 b$ 以上 (図 2 参照)の高さを確保する。従って、 スリット段数 $m$ は、次式も満足する必要がある。

$$
\frac{H-m l}{m} \geq b
$$

以上の諸式に基づいて、スリット入り鋼板耐震壁の設計手順を図 3 に示す。はじめに、鋼板を設置する骨組の柱間距離から鋼板の幅 $B$ を、梁間距離から接合部を除いた鋼板の高さ $H$ を決定する。ここで はスリット入り鋼板耐震壁をスパン全面に配置することとしている。 この接合部の高さは、過去のスリット入り鋼板の実施工例 ${ }^{12)}$ では、 上下とも $200 \mathrm{~mm}$ 程度を必要としている。さらに、設計上、スリッ 卜入り鋼板耐震壁に期待したい必要剛性 $K_{\text {req }}$ と必要耐力 $Q_{r e q}$ を決定 する。次いで、耐震壁に用いる鋼板の板厚 $t$ を選択し、式(1)および (3)に基づいて必要剛性 $K_{\text {req }}$ および必要耐力 $Q_{\text {req }}$ を満たすような柱状 部のアスペクト比 $\alpha$ 、柱状部の述べ高さが鋼板高さ $H$ に占める割 合 $\beta$ を求める。その後、式(7)に基づいて柱状部の幅厚比 $b / t$ が閾值 を下回るようなスリット段数 $m$ を求める。以上の手順により、鋼板 耐震壁のスリット形状 $(l, b 、 m)$ が決定され、壁部高さの条件式(8) を満たしていれば設計を終了する。一方、式(8)が満たされない場合、 鋼板厚 $t$ を変更して再設計する。

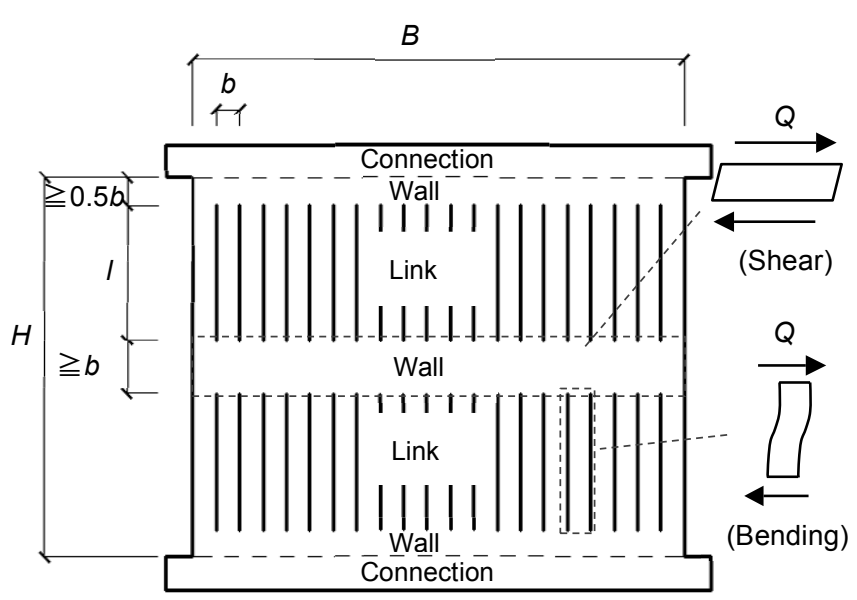

Fig.2 Deformation of slit shear wall 


\section{3. 実験概要}

\section{1 試験体概要と使用材料特性}

極低降伏点鋼 LY100を用いた多段スリット入り鋼板の耐震性能を 検証するため、準静的載荷実験を実施した。

試験体は、極低降伏点鋼 LY100 を用いたスリット入り鋼板を 3 体、 LY100 との比較対象となる普通鋼 SS400 1 体とする。試験体の設 計では、適用対象建物として文献 13)に記載された SAC の 9 層モデ ルを想定した。層間変形角 $1 \%$ において対象建物基準階ベースシア 一を、一構面あたりおよそ 0.05 向上させる耐力（850kN）をスリッ ト入り鋼板耐震壁に付与することとした。また、弾性限層間変形角 に関しては、梁先行降伏型の鋼構造建物の弾性限層間变形角を $1 \%$ と仮定し、普通鋼試験体はその約 $1 / 4$ 、極低降伏点鋼試験体は更な る早期降伏を期待してその約 1/8 の変形角で降伏するよう初期剛性 を調整し、それぞれ $83 \mathrm{kN} / \mathrm{mm} 、 160 \mathrm{kN} / \mathrm{mm}$ と定めた。

上記の実大モデルに対して、縮小率 1/2.4 で設計した試験体の詳 細を図 4、図 5 および表 1 に示す。実験で使用する鋼板として、板 厚 $9 \mathrm{~mm}$ の極低降伏点鋼 (LY100、降伏応力 $96 \mathrm{MPa}$ 、引張強さ 269MPa) と、 $4.5 \mathrm{~mm}$ の普通鋼 (SS400、降伏応力 $304 \mathrm{MPa}$ 、引張強さ $431 \mathrm{MPa}$ ) を用いた。

極低降伏点鋼の試験体は、LY-2 が 2 段スリット、LY-3 が 3 段スリ ット、LY-6 が 6 段スリットで、式(1)および(3)に基づいて、剛性と 耐力がともに各試験体でほぼ同じになるよう設計した。各試験体の 壁部の高さは柱状部の幅以上確保されており、式(8)の条件を十分に 満たしている。幅と柱状部の幅厚比は、段数が増えるほじ小さくな る関係にあり、試験体 LY-2 が 7.9、LY-3 が 5.1、LY-6 が 2.6 となる。

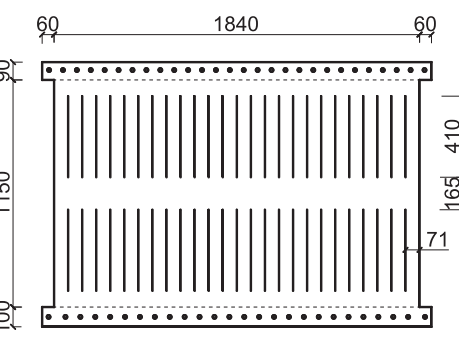

(a) LY-2 60

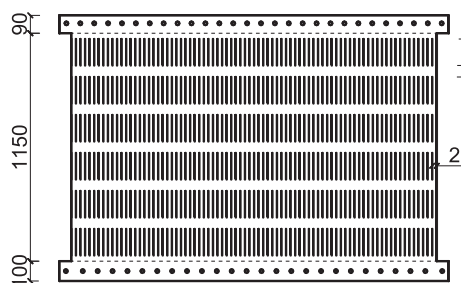

(c) LY-6
$6001840 \quad 60$

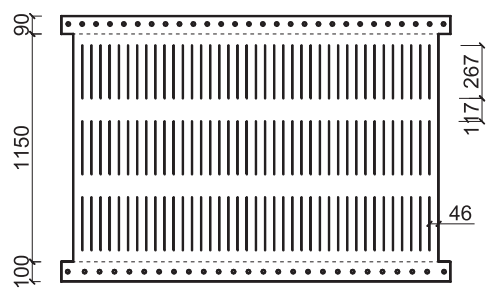

(b) LY-3

60

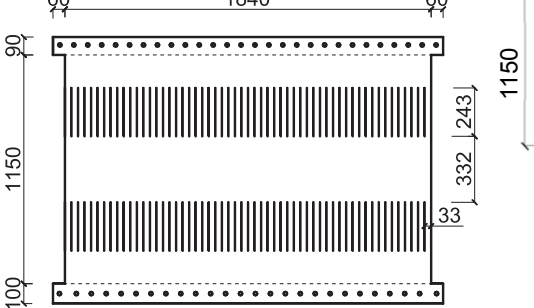

(d) $\mathrm{SS}-2$
Fig.4 Specimens (unit: $\mathrm{mm}$ )
(1)鋼板の幅 $B$ 、高さ $H$ 、必要耐力 $Q_{r e q}$ 、必要 剛性 $K_{\text {req }}$ を対象建物より決定

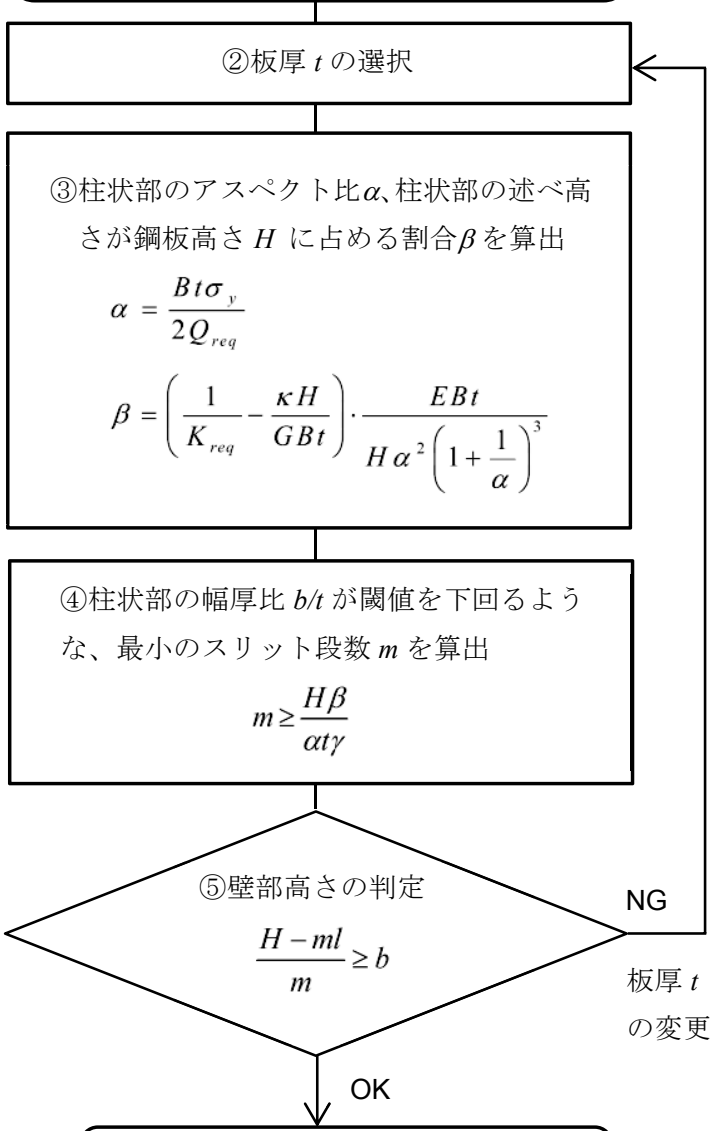

(6)スリット形状 $(l, b, m)$ の決定

Fig.3 Design flow chart of slit shear wall

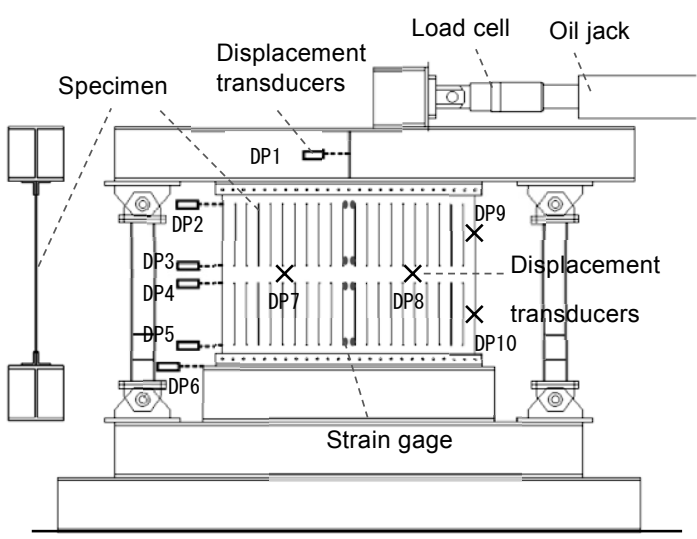

Fig.5 Loading condition and measurement (LY-2)

Table 1 Material properties and specimens

\begin{tabular}{|c|c|c|c|c|c|c|c|c|c|c|c|}
\hline \multirow[b]{2}{*}{ 試験体名 } & \multicolumn{5}{|c|}{ 鋼材 } & \multicolumn{3}{|c|}{ 試験体形状 } & \multicolumn{3}{|c|}{ 試験体性能 } \\
\hline & 鋼種 & $\begin{array}{l}\text { 板厚 } t \\
(\mathrm{~mm})\end{array}$ & $\begin{array}{l}\text { 降伏応力 } \\
\sigma_{y}(\mathrm{MPa})\end{array}$ & $\begin{array}{l}\text { 引張強さ } \\
\sigma_{y}(\mathrm{MPa})\end{array}$ & $\begin{array}{c}\text { 破断ひずみ } \\
\varepsilon_{u}(\%)\end{array}$ & $\begin{array}{l}\text { スリット } \\
\text { 段数 } m \\
\end{array}$ & \begin{tabular}{|} 
アスペクト \\
比 $\alpha$
\end{tabular} & $\begin{array}{c}\text { 幅厚比 } \\
b / t\end{array}$ & $\begin{array}{c}\text { 初期剛性 } K \\
(\mathrm{kN} / \mathrm{mm})\end{array}$ & $\begin{array}{c}\text { 弾性限層間 } \\
\text { 変形角 }(\%) \\
\end{array}$ & $\begin{array}{c}\text { 全塑性耐力 } \\
Q_{u}(\mathrm{kN})\end{array}$ \\
\hline LY-2 & LY100 & 9 & 96 & 269 & 65 & 2 & 5.8 & 7.9 & 70 & 0.11 & 137 \\
\hline LY-3 & LY100 & 9 & 96 & 269 & 65 & 3 & 5.8 & 5.1 & 72 & 0.11 & 137 \\
\hline LY-6 & LY100 & 9 & 96 & 269 & 65 & 6 & 5.8 & 2.6 & 72 & 0.11 & 137 \\
\hline$S S-2$ & SS 400 & 4.5 & 304 & 431 & 27 & 2 & 7.2 & 8.1 & 41 & 0.23 & 162 \\
\hline
\end{tabular}


これらを比較することで、耐力劣化と柱状部の局部座屈、およびそ れに伴うエネルギー消費性能の低下に関する幅厚比の影響を考察す る。

試験体 SS-2 は、スリットを 2 段とした SS400 鋼板を用いる。な お極低降伏点鋼 LY100を用いた試験体における等方硬化成分を考え、 設計で想定した層間変形角 $1 \%$ の耐力が、試験体 LY-2 と試験体 SS-2 でほぼ一致するよう、後述する有限要素法解析を援用し耐力を調整 した。また、試験体 SS-2 の弾性限層間変形角は、試験体 LY-2 の 2 倍としており、本研究が提案するLY100スリット入り鋼板耐震壁が、 早期降伏と大変形下での安定挙動の両方を満足させうるのかを、普 通鋼に対して比較検証する。

\section{2 載荷装置と載荷条件}

本実験で使用する載荷装置を図 5 に示す。試験体は二つの L 字ア ングルを介して高力ボルトで載荷装置の梁に取り付け、油圧ジャッ キを用いて水平変位を与える。載荷履歴は、層間変形角で $0.05 \%$ 、 $0.25 \% 、 0.5 \% 、 0.75 \% 、 1.0 \% 、 1.25 \% 、 1.5 \% 、 1.75 \% 、 2.0 \% 、 2.5 \%$ 、 $3.0 \% 、 3.5 \% 、 4 \% を 2$ 回ずつと、4.5\%を 1 回与える正負交番漸増繰 り返し載荷とした。

\section{3 計測計画}

図 5 に計測計画を示す。層間変形角は、上梁の水平変位計 DP1 と 下梁の DP6 の差である水平相対変位を、鋼板高さ $H=1150 \mathrm{~mm}$ で除 した值と定義する。また、試験体 LY-2 を例として図 5 に示すように、 柱状部における各段両端の水平変位(図 5 では、上側の柱状部は DP2 と DP3、下側は DP4 と DP5）に基づく柱状部の相対変位を、柱状部 高さ $l$ で除した值を柱状部変形角と定義する。なお、この柱状部変 形角は、試験体 LY-2 と LY-3 は全段、LY-6 は下から 1 段目、3 段目、 5 段目を計測した。さらに、試験体の面外変形を計測するため、変 位計 DP7 と DP8 を鋼板中央高さ、鋼板端部から 1/4 幅の位置に取り 付け、DP9 と DP10を鋼板端部の柱状部中央高さに取り付けた。

ひずみゲージを鋼板中央の柱状部に貼付し、各段の柱状部外縁部 のひずみ分布を測定した。ひずみゲージの貼付位置は文献1)に従い、 図 6 に示寸ように極端なひずみ集中の起きる場所を避け、スリット から $3 \mathrm{~mm}$ 、柱状部端部から $10 \mathrm{~mm}$ の位置を中心とした。

\section{4. 有限要素法解析}

本論では、有限要素解析プログラム ABAQUS ${ }^{14)}$ を用いた解析によ って、スリット入り鋼板試験体の変形性状と応力分布に関する実験 結果を補完する。図 7 に試験体 LY-2 の解析モデルを示す。モデルは シェル要素（S4R）を用いて作成した。

解析におけるスリットの幅は実験の試験体のものとほぼ同等であ る $0.5 \mathrm{~mm}$ とし、スリット端部は半円とした。ここで、試験体と同様 に鋼板が取り付く梁は鋼板に対し十分に剛であると仮定し、解析モ デルの境界条件は下端を完全固定とし、上端は $z$ 軸の変位と $x y z$ 軸 の回転を拘束した。実験の載荷装置には両端ピンの剛な柱材が取り 付いているため、柱の回転による鉛直変位を算出し、それを $y$ 軸の 変位とした。また、初期不整として、鋼板の中央高さに、 $z$ 軸方向 で鋼板高さの $1 / 500$ に相当する変位を与えた ${ }^{5)}$ 。鋼板のメッシュサ イズは、基本的に柱状部幅の $1 / 5$ 程度とした。ただし、スリット端 は応力が集中するため柱状部幅の $1 / 15$ 程度とさらに細かく分割し た。なお、鋼板のメッシュサイズを柱状部幅の $1 / 30$ とした解析も別 途実施したが、履歷特性や座屈性状などに差異は見られなかった。

解析における鋼材の構成則は、いずれも表 1 の材料特性に準じた トリリニアモデルとした。ここで、普通鋼 SS400 は一次勾配をヤン グ係数 $E=205 \mathrm{GPa}$ 、二次勾配 $E / 150$ と設定した。一方、極低降伏点 鋼 LY100 では、普通鋼に対する降伏比の小ささを考慮し、一次勾配 を $E$ 、二次勾配 $E / 80$ と設定した。なお、極低降伏点鋼の材料特性は 移動硬化成分と等方硬化成分の組み合わせ ${ }^{15)}$ により表す必要がある。 本論では、移動硬化成分を先に示したトリリニアモデルと設定し、 等方硬化成分は別途実施した、極低降伏点鋼 LY100の 1 段スリット 入り鋼板（本論の LY 試験体と同一ロット材）の繰り返し水平載荷 実験 ${ }^{16)}$ を適切に再現できるよう構成則の変数を調節した。

\section{5. 実験結果}

\section{1 剛性および耐カの検証}

各試験体のせん断力一層間変形角関係を図 8 に示す。図 8 中の実 線は正負交番繰り返し実験の結果を、一点鎖線は式(1)に基づく算定 初期剛性を、二点鎖線は式(2)および式(3)に基づく算定弾性限耐力と 算定全塑性耐力を表す。

載荷終了後の写真を図 9 に示す。LY 試験体 3 体には亀裂が発生し

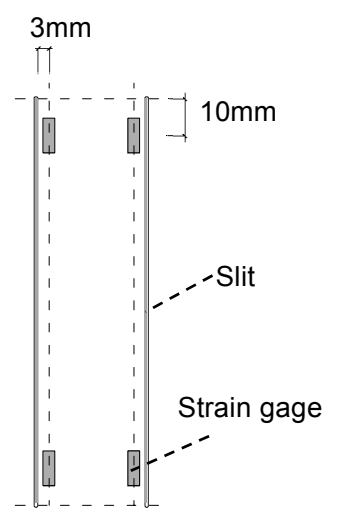

Fig.6 Placement of strain gages

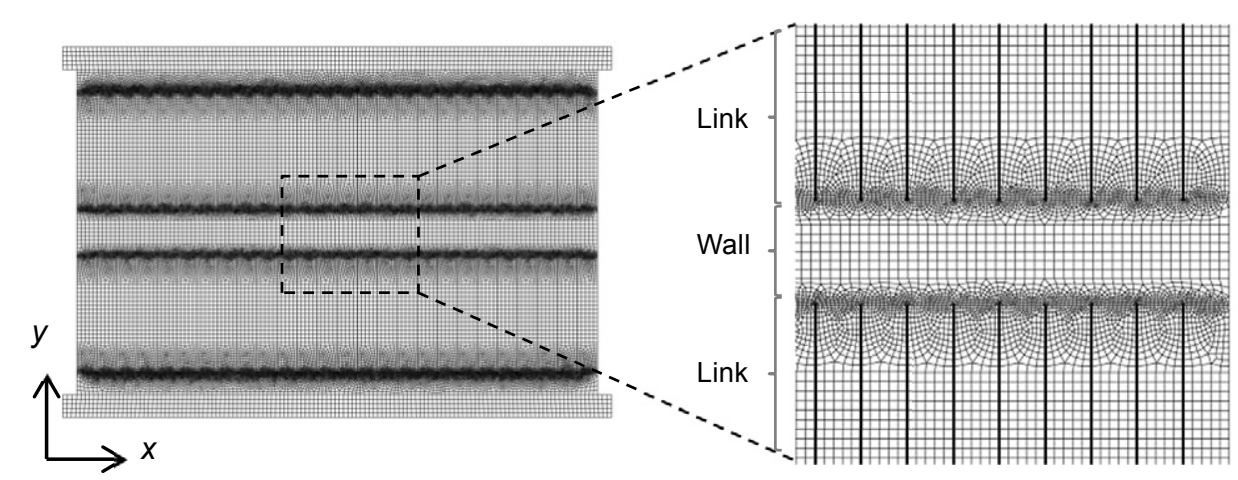

Fig.7 Mesh in FEM analysis (LY-2) 
なかったが、普通鋼を用いた SS-2 では層間変形角 $2.5 \%$ で下段のス リット端部に亀裂が発生した。図 10 は、載荷終了後の SS-2 柱状部 （1 段目）の亀裂進展状態を示す。また、LY-2 は 3.5\%で柱状部に局 部座屈が発生したが、LY-3、LY-6 では局部座屈は確認されなかった。

表 2 に弾性範囲内である $0.05 \%$ 載荷時の割線として求めた初期剛 性、柱状部に添付したひずみゲージの值が鋼材の塑性ひずみに達し た際の降伏耐力、層間変形角 $1 \%$ 時耐力および層間変形角 $4.5 \%$ まで の最大耐力を示す。各試験体において、初期剛性の実験值は式(1) に基づく算定值に対して 96\%〜98\%の範囲にあり、極めて精度よく 一致している。また、降伏耐力は式(2)に基づいて算定した弾性限耐 力 $Q_{y}$ に対し $98 \%$ \% $111 \%$ の範囲にあり、こちらも対応が良好である。

3.1 節に記したように、4 体の試験体は極低降伏点鋼の等方硬化成 分等を考慮した上で、層間変形角 $1 \%$ で耐力がおおむ敉等しくなる よう式(3)に基づく算定全塑性耐力 $Q_{u}$ の值を調整しており、その結 果、実験における各試験体の耐力差は $8 \%$ 以内に留まっている。こ こで、変形角 $1 \%$ 時の耐力がほぼ同一である LY 試験体と SS 試験体 を比較すると、算定值に対する実験值の比は LY 試験体が $1.3 \sim 1.4$ 、 試験体 SS-2 が 1.1 となった。式(3)に基づく算定全塑性耐力 $Q_{u}$ は安 全側の值を与えるが、繰り返し載荷に伴う極低降伏点鋼の大きなひ ずみ硬化成分と等方硬化成分から、LY 試験体では鋼板の耐力は過小 評価される。

一方、算定全塑性耐力に対寸る実験最大耐力の比に関しては、LY
試験体が 2.0〜2.4 と非常に大きな值を示したのに対し、試験体 SS-2 は層間変形角 $1 \%$ とほぼ等しい 1.1 であった。LY 試験体のせん断力 一層間変形角関係図 8(a)〜(c)によれば、ひずみ硬化成分と等方硬化 成分による極低降伏点鋼の等価降伏応力上昇は層間変形角 $1 \%$ 以降 ほとんど見られず、図中第 1 象限と第 3 象限の耐力上昇は、鋼板に 張力場が形成されたことに起因する。ここで、本論で用いた LY100 の降伏応力に対する引張強さの比は 2.8 であり、降伏応力の代わり に引張強さを用いて全塑性耐力を算定すると、実験の最大耐力は算 定值の $70 \%$ ～ $85 \%$ となる。よって、層間変形角 $4.5 \%$ 内の LY 試験体 の最大耐力は、式(3)の算定に鋼材の降伏応力ではなく引張強さを用 いることで、周辺骨組に対しても安全側の評価を行うことが可能で ある。

\section{2 多段スリットのせん断変形角分布}

図 11 に、層間変形角 $1 \%$ までの各試験体における柱状部変形角の 推移を示す。極低降伏点鋼を使用した試験体 3 体では、層間変形角 $1 \%$ 時点での各段の柱状部変形角の比がいずれも 1.1 未満と、各段に 均等にせん断変形が分配されている。一方、SS-2では、載荷直後か ら 1 段目と 2 段目で変形量が異なっており、層間変形角 $1 \%$ 時点で は 1 段目に対する 2 段目の変形量の比が 2.4 と、大きく差が開いた。

スリット入り鋼板試験体の柱状部変形角分布と、スリット端の塑 性ひずみ分布の関連をより詳細に検証するため、4 章で述べた有限

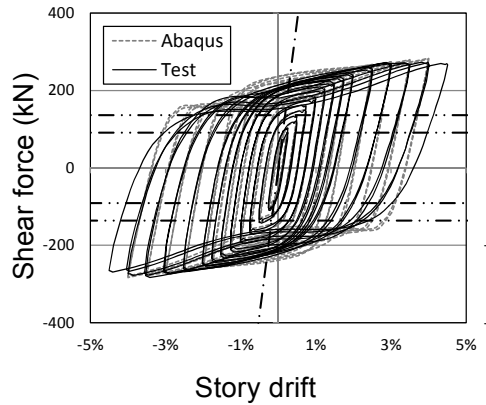

(a) LY-2

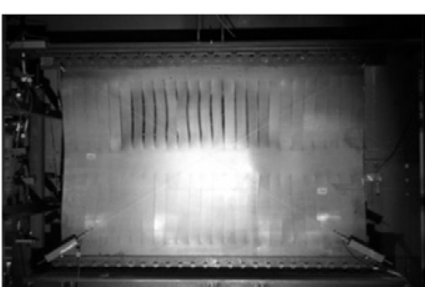

(a) LY-2
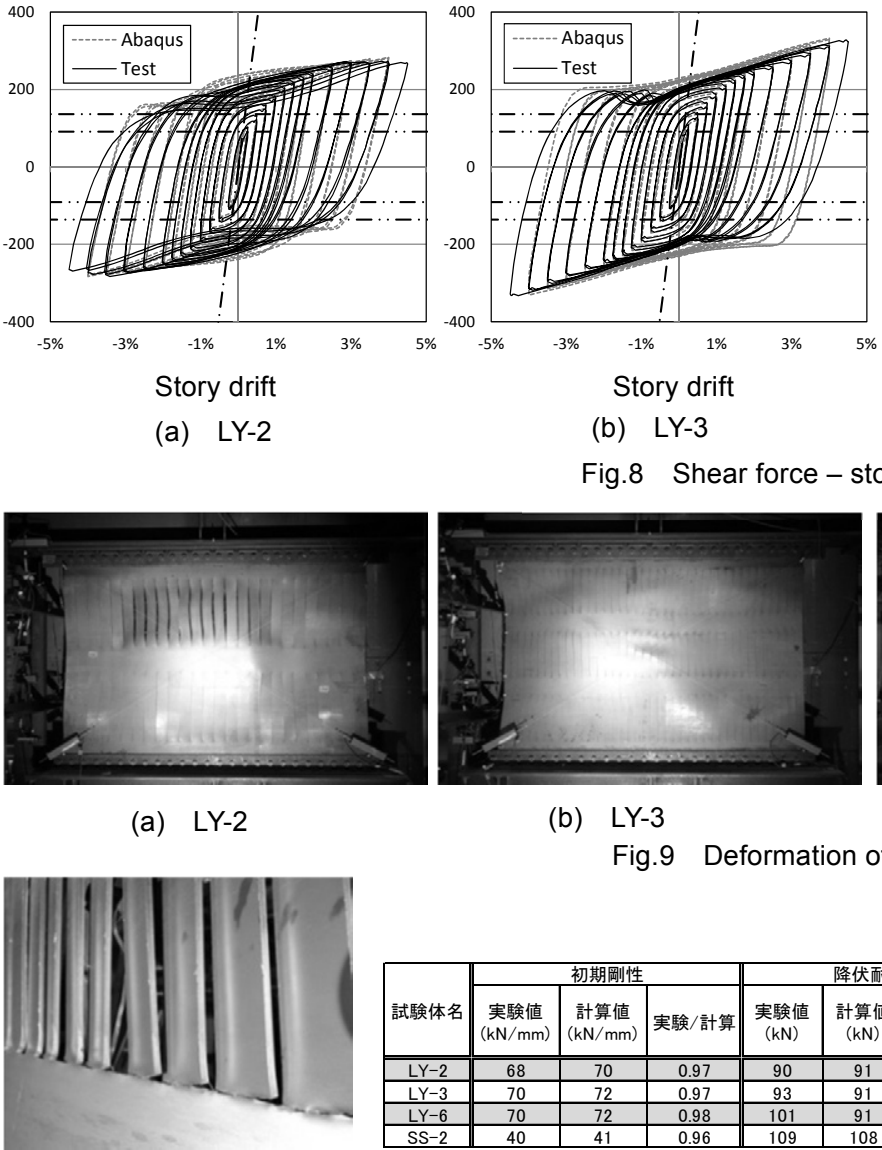

(b) LY-3

Fig. 8 Shear force - story drift relationship

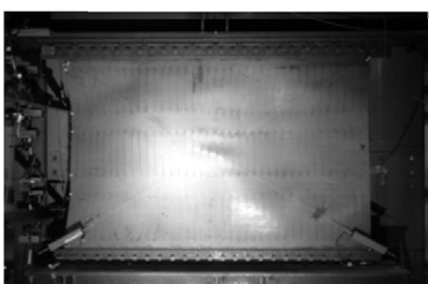

(b) LY-3

Fig.9 Deformation of specimens

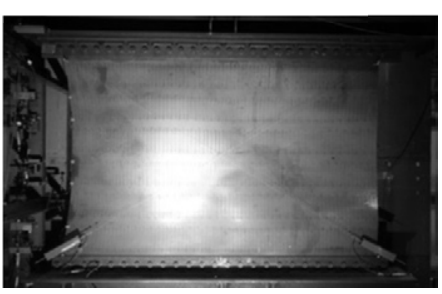

(c) LY-6

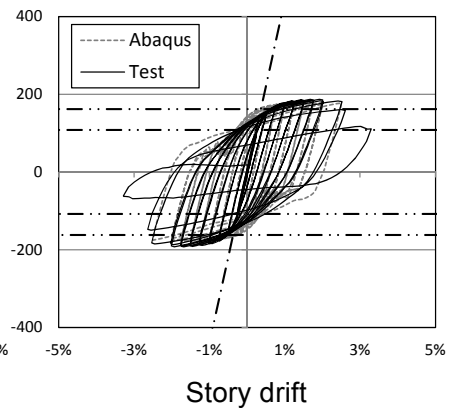

(d) SS-2

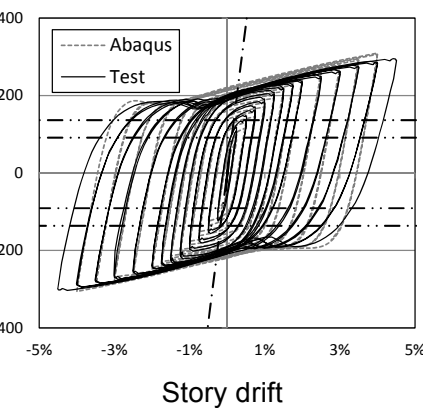

(c) LY-6

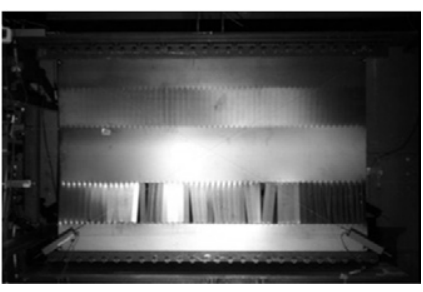

(d) SS-2

Table 2 Test results

\begin{tabular}{|c|c|c|c|c|c|c|c|c|c|c|c|c|c|c|}
\hline \multirow[b]{2}{*}{ 試験体名 } & \multicolumn{3}{|c|}{ 初期剛性 } & \multicolumn{3}{|c|}{ 降伏耐力 } & \multicolumn{3}{|c|}{ 全塑性利力到達時変形角 } & \multicolumn{5}{|c|}{ 全塑性耐力・1\%時耐力·最大耐力 } \\
\hline & 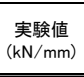 & 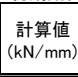 & 実験/計算 & $\begin{array}{c}\text { 実験值 } \\
(\mathrm{kN})\end{array}$ & 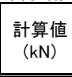 & 実験/計算 & 実験值 $(\%)$ & 計算値 $(\%)$ & 実験/計算 & \begin{tabular}{|c} 
算定全塑 \\
性耐力 $Q_{u}$ \\
$(\mathrm{kN})$
\end{tabular} & 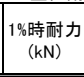 & 1\%時利力 & $\begin{array}{l}\text { 最大利力 }_{(\mathrm{kN})} \\
\end{array}$ & \begin{tabular}{|l|} 
最大利力 \\
算定全塑性 \\
\end{tabular} \\
\hline LYY-2 & 68 & 70 & 0.97 & 90 & $\frac{9}{9}$ & 0.98 & 0.51 & 0.25 & 2.04 & $\frac{\cos 1}{137}$ & 18 & 1.32 & 271 & 1.98 \\
\hline LYY-3 & 70 & 12 & 0. & 93 & 9 & 1.0 & 0.5 & & 2 & 137 & 1 & & & $\frac{2.36}{212}$ \\
\hline$L Y-6$ & 70 & 72 & 0.98 & 101 & 91 & $\frac{1.11}{1.11}$ & 0.51 & 0.25 & 2.04 & 137 & 191 & 1.39 & 290 & 2.12 \\
\hline $\begin{array}{ll}\frac{1}{s}-6 \\
s s-2\end{array}$ & 40 & $\frac{71}{41}$ & 0.96 & 109 & $\frac{31}{108}$ & 1.01 & 0.60 & 0.51 & $\frac{2.048}{1.18}$ & $\frac{151}{162}$ & 177 & 1.10 & $\frac{290}{185}$ & $\frac{.12}{1.14}$ \\
\hline
\end{tabular}

Fig.10 Fracture (SS-2) 
要素法解析を用いる。図 8 中に破線で示すように、有限要素法解析 におけるせん断力一層間変形角関係は、図中に実線で示した実験結 果と概ね良好に対応している。

図 12 は、有限要素法解析における層間変形角 2.5\%（試験体 SS-2 のスリット端部に亀裂が発生した変形角）での各試験体の変形分布 と塑性ひずみ分布を表す。有限要素法解析における各段の柱状部変 形角分布に関しても、LY 試験体 3 体は特定の段への変形集中が見ら れないのに対し、SS-2では 1 段目にのみせん断変形が集中している ことが確認でき、2 段目に対する 1 段目の柱状部変形角の比は 5.2 にまで到達した。実験においても、層間変形角 $2.5 \%$ 時の柱状部変形 角の比は 4.5 と $1 \%$ 時よりさらに大きくなっている。

図中の白い領域は弾性範囲内、黒い領域は鋼材の塑性化部位を示 す。柱状部変形角分布と同様に、塑性ひずみ分布でも LY 試験体 3 体では各段スリット端部の最大塑性ひずみ量の比は 1.2 未満に抑え られていた。これに対し、試験体 SS-2では 1 段目のスリット端部に 塑性化が集中しており、最大塑性ひずみ量比は 2.7 であった。

また、解析結果における層間変形角 $2.5 \%$ でのスリット端周辺の 最大塑性ひずみ量を比較すると、SS-2 は LY-2の 1.6 倍の值を示した。 これは、LY-2 において極低降伏点鋼のひずみ硬化および等方効果成 分により塑性ひずみがスリット端部周辺に分散し、ひずみの局所集 中を抑制できたことを示している。本論 1 章に記したように、極低 降伏点鋼を用いたスリット入り鋼板には、ひずみ硬化成分および等 方硬化成分によるスリット各段への変形の均等分配と、スリット端 への塑性ひずみの集中阻止を期待したが、本節の考察からそれが実 証された。

以上から、補剛材等を用いない多段のスリット入り鋼板を考えた 場合、普通鋼では特定の段への変形集中とそれに伴う鋼材の亀裂が 発生し得るのに対し、極低降伏点鋼を用いた場合は段数に関わらず 均等にせん断変形が分配され、鋼材の亀裂や破断を防ぐことが可能 である。

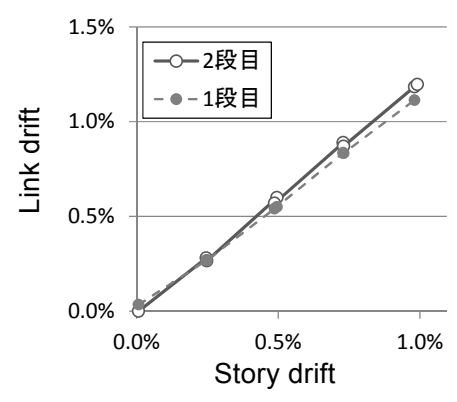

(a) LY-2

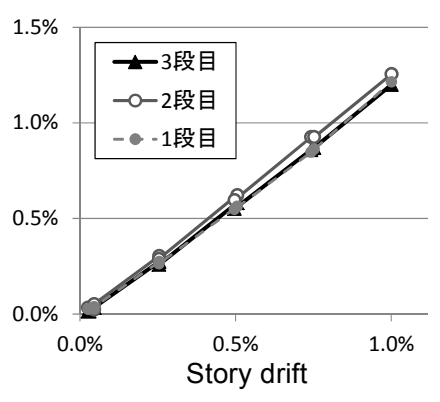

(b) LY-3

\section{3 鋼板全体の面外変形量}

試験体 LY-2 と SS-2 の面外変形量の推移は以下の通りである。両 試験体の面外変形量を、変位計 DP7 と DP8 (図 5 参照) の平均変形 量值で定義するとき、試験体 LY-2 では、鋼板高さ $H$ に対する面外 変形量は、層間変形角 $0.11 \%$ （弾性限）で $1 / 3000$ 以下、 $1 \%$ で $1 / 400$ 以下、 $2 \%$ で $1 / 80$ 以下と、顕著な面外変形は起こっていない。なお、 試験体 LY-3 と LY-6 における面外変形量は、LY-2 よりさらに小さい ものであった。一方、試験体 SS-2 では、層間変形角 $0.23 \%$ (弾性限) で $1 / 1600$ 以下、 $1 \%$ で $1 / 160$ 以下、 $2 \%$ で $1 / 80$ 以下と、極低降伏点鋼 を用いた LY-2 よりやや大きいものの、それでも面外変形はなお限ら れている。また、DP9 と DP10 より計測した鋼板端部の面外変形量 は、試験体 4 体のいずれも、水平荷重が設計耐力に到達した層間変 形角 $1 \%$ のサイクルで、鋼板厚以下（最大で板厚の $71 \%$ ）に収まっ ていた。

さらに、図 8 のせん断力一層間変形角関係が示すように、試験体 4 体はいずれも、変形が進展しても顕著な耐力劣化のない安定した 履歴挙動を示している。以上から、本論の提案するスリット入り鋼 板耐震壁は、面外補剛材を配すことなしに、安定した面内変形挙動 を保証している。これは、本論では鋼板のアスペクト比が 1 未満の 全スパン型の耐震壁を想定しているため、鋼板端部に発生する転倒 モーメントによる軸力 ${ }^{11}$ が、比較的小さいためである。ただし、実 建物一の適用を考えた場合、提案耐震壁に所定の性能を発揮させる には、鋼板が取り付く梁の曲げ剛性およびせん断剛性と、両サイド の柱の軸剛性が十分大きいことが条件となる。

また、面内に加えて面外に強制変形を受ける場合（2 軸載荷）に ついても、解析からその影響を検証した。解析では、面内変形と同 じ変位を面外方向にも与え、層間変形角 $4 \%$ までの正負交番漸増繰 り返し載荷とした。本 2 軸載荷では、ゼロ変位の耐力が 1 軸載荷に 比べ $5 \%$ （層間変形角 1\%以降平均）低下したが、これによるエネル ギー消費量の低下は層間変形角 4\%時においても7\%程度に留まって

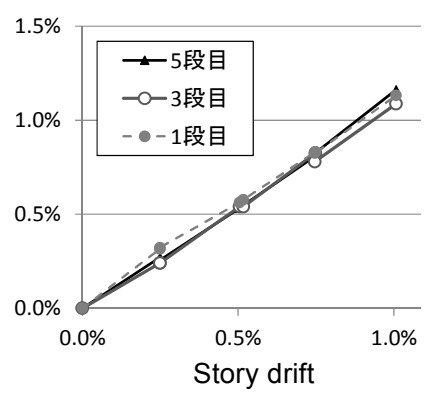

(c) LY-6

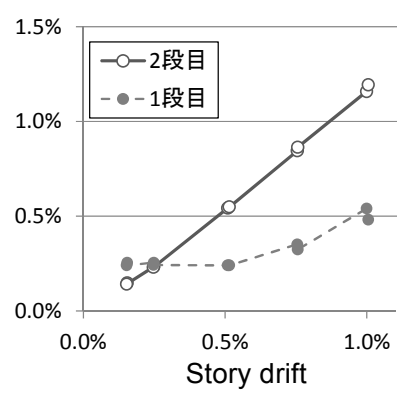

(d) SS-2

Fig.11 Distribution of shear deformation

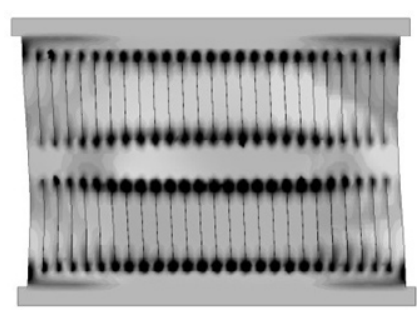

(a) LY-2

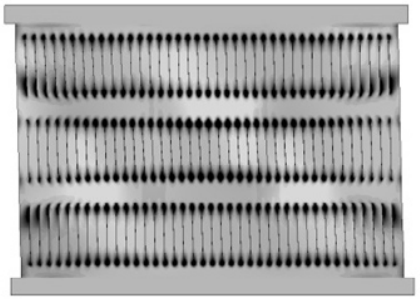

(b) LY-3

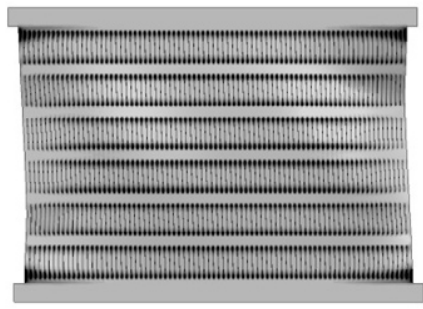

(c) LY-6

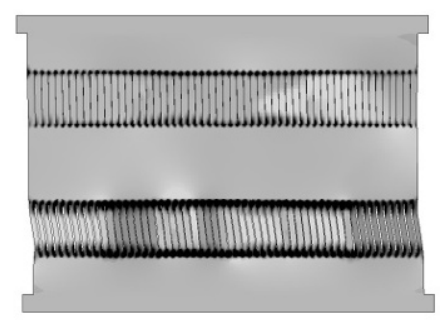

(d) SS-2

Fig.12 Stress distribution in FEM analysis 


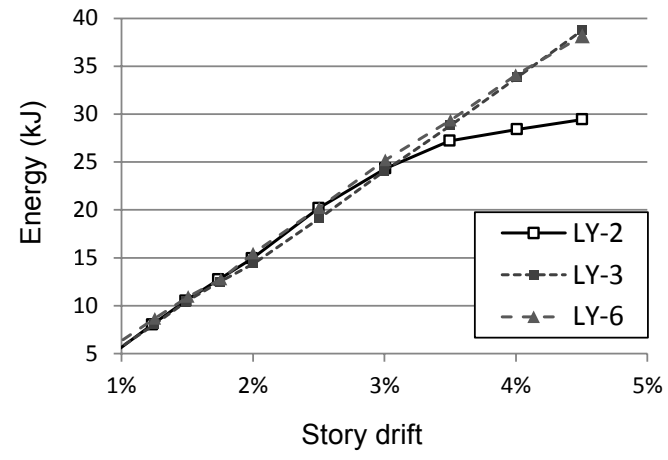

Fig.13 Energy dissipation per one cycle

いた。以上から、本論で提案する耐震壁は、面外方向にも変位を受 ける場合も、面内に関しては安定した耐力およびエネルギー消費能 力を発揮し得る。

\section{4 終局挙動}

図 13 に LY 試験体の各サイクルにおけるエネルギー消費量の推移 を示す。LY-2 と LY-3 を比較すると、層間変形角 $3 \%$ まで双方のエネ ルギー消費量はほぼ等しい。しかし、層間変形角 3.5\%で LY-2 の柱 状部に局部座屈が生じると、履歴挙動にはピンチングが発生し、層 間変形角 4.5\%時のエネルギー消費量は LY-3 の 8 割程度に低下した。 一方、ともに局部座屈が発生しなかった LY-3 と LY-6 を比較すると、 エネルギー消費量は 2 体の間で載荷終了時までほぼ差がなく、ほぼ 同等のエネルギー消費性能が確保できている。

普通鋼を対象とした文献 1 )では、柱状部の幅厚比 $b / t \leqq 10$ を満 た寸試験体において、耐力劣化が抑止できることを確認している。 ここで、降伏応力で基準化した幅厚比を考えると、極低降伏点鋼 LY100 を用いた場合、普通鋼を用いた同寸法のものより基準化幅厚

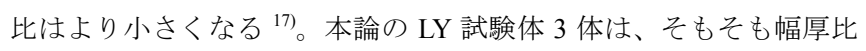
が 7.9 （LY-2）、5.1（LY-3）、2.6（LY-6）といずれも 10 以下であるた め、実験において耐力劣化が発生しなかった事実は、文献 1)の所見 と整合している。

しかし、層間変形角 $3.5 \%$ 超える大変形下では、3 体の中で最も 幅厚比の大きい LY-2 に局部座屈が発生し、履歴挙動にピンチングを 確認した。文献 1$)$ でも、幅厚比 $b / t \leqq 10$ を満たす試験体では、耐 力劣化は抑止されているが、局部座屈の発生と多少のピンチングは 許容している。一方、幅厚比が 5.1 の試験体 LY-3 と、2.6の試験体 LY-6 では、層間変形角 4\%においても局部座屈は発生しなかった。 LY-2 のゼロ変位の荷重が変形進行に伴い低下し続け、層間変形角 $4.5 \%$ で最大值に対し $60 \%$ 程度まで減少したのに対し、LY-3 と LY-6 の場合は 95\%程度の值を保持し、ピンチングは僅かなものであった。

図 8 にあるように、LY-3 やLY-6 のせん断力一層間変形角関係に おいても、層間変形角 $3 \%$ 前後あたりからゼロ変位近傍で荷重が若 干低下しているが、これは大変形領域で鋼板全体が僅かに面外変形 することに依っている。これについて、文献 1)が鋼板両端にスチフ ナを配して面外補剛を行っていたことを踏まえて、鋼板両端の面外 変位を拘束した解析を実施し、エネルギー消費性能の変化を調べた。 その結果、面外変位を拘束することでゼロ変位での荷重は層間変形 角 $1 \%$ 以降の平均で $7 \%$ 程度上昇したが、エネルギー消費量の上昇は 層間変形角 $4 \%$ 時においても僅か $6 \%$ 程度に留まっていた。
以上より、本論は極低降伏点鋼を用いたスリット入り鋼板耐震壁 に対して、耐力劣化のない安定的な変形挙動が期待できる柱状部の 幅厚比 $b / t$ の閾值 $\gamma$ を 10 と設定する。なお、本論の実験に基づけば、 幅厚比 $b / t$ を 5 以下と設計した場合、鋼板は層間変形角 $4 \%$ まで柱状 部の局部座屈とそれに伴う履歴挙動のピンチングをも防ぐことがで きる。

普通鋼を用いた SS-2 では、塑性率がおよそ 10 となる層間変形角 $2.5 \%$ の載荷においてせん断変形が 1 段目の柱状部に集中し、スリッ 卜端部から水平方向に亀裂が発生、進展した（図 10）。これにより、 試験体は層間変形角 $3 \%$ で耐力が急激に低下し始め、正負 1 サイク ル終了時に剛性と耐力をほぼ喪失し終局に至った。一方、LY 試験体 3 体では、層間変形角 $4.5 \%$ においても亀裂が全く発生していない。

ここで、スリット端部の亀裂発生に関して、LY 試験体と SS 試験 体の勒性を比較すれば、SS 試験体は塑性率が 10 (層間変形角 2.5\%) で亀裂発生がみられるのに対し、LY 試験体は 37(層間変形角 4.5\%) に至っても亀裂が発生せず、極めて高い塑性変形能力が確保できて いる。表 1 によれば、鋼材としての破断ひずみは LY100 が 65\%に対 して SS400 が 27\%と、その差は 2.4 倍である。一方、実験に基づく スリット入り耐震鋼板壁の塑性変形能力は、3.7 倍（LY 試験体と SS 試験体の到達塑性率の比）以上であることを示している。これは 5.2 節に示したように、極低降伏点鋼特有の大きな等方硬化成分および ひずみ硬化成分により等価降伏応力が上昇し、特定の段への変形集 中が抑制され、さらにスリット端部周辺に塑性ひずみが分散された ことに起因する。

\section{6. まとめ}

極低降伏点鋼 LY100 を用いたスリット入り鋼板耐震壁と、普通鋼 SS400 を用いた鋼板而震壁の性能を、準静的載荷実験を中心に比較 検討した結果、以下の知見を得た。

1）極低降伏点鋼を用いたスリット入り鋼板耐震壁の初期剛性と弾 性限耐力は、既往の算定式で精度よく評価できる。また、柱状部 の全塑性モーメントに基づく最大耐力評価は、実験值に対して常 に安全側の評価を与える。さらに、極低降伏点鋼を用いた試験体 では、(1)ひずみ硬化成分、(2)等方硬化成分、(3)張力場の形成に起 因して、極大地震下で想定される層間変形角 $1 \%$ 上上の大変形にお いても、耐力の上昇が認められる。

2) 本論で提案するスリット入り鋼板耐震壁は、補剛部材等を配さ ずとも十分な面内変形能力を発揮し、層間変形角 $1 \%$ 超える大変 形下においても、耐力劣化のない安定した挙動を確保し得る。

3) 普通鋼を用いた 2 段スリット入り鋼板試験体では、せん断変形 が 1 段目の柱状部に集中し、層間変形角 $1 \%$ での 1 段目と 2 段目の 柱状部変形角の比は 2.4 に達した。一方、極低降伏点鋼を用いた 試験体では、等方硬化成分とひずみ硬化成分により、せん断変形 が各段に均等に分配され、柱状部変形角の比は 1.1 末満に留まっ た。

4) 普通鋼を用いたスリット入り鋼板試験体では、層間変形角 $2.5 \%$ において変形が集中した 1 段目のスリット端に亀裂が発生した。 一方、極低降伏点鋼を用いた試験体では、層間変形角 $4.5 \%$ まで亀 裂は確認されず、その塑性変形能力は普通鋼の 3.7 倍以上であっ た。これは、極低降伏点鋼が持つ材料としての勒性の大きさに加 
え、等方硬化成分とひずみ硬化成分に起因して、スリット端の塑 性ひずみがその周辺に分散低減されたためである。

5) 極低降伏点鋼を用いたスリット入り鋼板耐震壁に対して、耐力 劣化のない安定的な変形挙動を期待するときには、柱状部の幅厚 比 $b / t$ は 10 以下の值であればよい。更に、幅厚比 $b / t$ を 5 以下まで 下げた場合、層間変形角 4\%に至るまで、柱状部には局部座屈が発 生せず、それに伴う履歴挙動のピンチングも防ぐことができる。

\section{参考文献}

1）日高桃子，松井千秋，今村輝武，畑戸龍夫：スリット入り鋼板响震壁の弾塑性性 状について, 日本建築学会構造系論文集, No.519, pp.111-117, 1999.05.

2）村部隆太郎，李麗：木・鋼ハイブリッド而力壁の構造性能に関する実験的研究 - そ の 1 鋼板の面外補強がない場合, 日本建築学会九州支部研究報告集, Vol.42, pp.433-436, 2003.03.

3) Hitaka T., Matsui C. : Experimental Study on Steel Shear Wall with Slits, Journal of Structural Engineering, ASCE, Vol.129, pp.586-595, 2003.05.

4) Cortes G., Liu J. : Experimental evaluation of steel slit panel-frames for seismic resistance, Journal of Constructional Steel Research, Vol.67, pp.181-191, 2011.02

5) 伊藤麻衣, 坪山紀子, 中島正愛 : 木質パネルで面外補剛されたスリット入り鋼板 の而震性能，日本建築学会構造系論文集，No.657，pp.2065-2071，2010.11.

6) Ke K., Chen Y.Y. : Design Method of Steel Plate Shear Wall with Slits Considering Energy Dissipation, 15th WCEE, Lisbon, Portugal, 2012.09.

7) Nakashima M., Iwai S., Iwata M., Takeuchi T., Konomi S., Akazawa T, Saburi K. : Energy dissipation behavior of shear panels made of low-yield stress steel, Journal of Earthquake Engineering and Structural Dynamics, Vol.23, No.12, pp.1299-1313, 1994.12.

8) Nakagawa S., Kihara H., Torii S., Nakata Y., Iwata M., Fujisawa K., Fukuda K. : Hysteretic behavior of low yield strength steel panel shear wall - experimental investigation -, 11th WCEE, Acapulco, Mexico, 1996.06.

9）熊谷仁志, 田村和夫, 柴慶治, 磯田和彦: 鉄骨梁および鋼材ダンパーで連結され た連層耐震壁架構に関する研究，コンクリート工学年次論文報告集，Vol.21， pp.355-360, 1999.06

10）岩田衛, 黄一華, 川合廣樹，和田章: 被害レベル制御構造「Damage Tolerant Structure」 に関する研究，日本建築学会技術報告集，No.1，pp.82-87，1995.12.

11）田中清, 鳥井次夫, 佐々木康人, 川合廣樹, 和田章, 岩田衛 : 極低降伏点鋼制震 パネルを用いた被害レベル制御設計法の高層建物への適用，日本建築学会技術報告 集, No.5, pp.126-131，1997.12.

12）松井千秋：これからの建築骨組システム，月刊鉄鋼技術，2001.06.

13) The SAC Steel Project, http://www.sacsteel.org/, 参照 2014.04.01

14) SIMULIA Inc., ABAQUS Version 6.9 User's Manual, http://abaqus.civil.uwa.edu.au/docs/abaqus/v6.7/, 参照 2013.09.01

15) 山田稳, 辻文三 : 等方+移動硬化モデルによる鋼材の応力-歪関係, 日本建築学会 近畿支部研究報告集，Vol.18, pp.253-256, 1978.05.

16）東鄉拓真, 和留生, 倉田真宏, 林和宏, 中島正愛 : X 形リンク付き鋼板而震壁の 健全性判定機能の強化と検証 - その 2 判定機能とエネルギー消費性能の検証実験, 日本建築学会大会学術講演梗概集，C-1，pp.1145-1146，2014.09.

17）田中清, 佐々木康人, 米山真一朗 : 鋼種が異なるせん断型パネルダンパーの静的 履歴特性に関する実験研究, 日本建築学会構造系論文集, No.520, pp.117-124, 1999.06. 


\title{
DEVELOPMENT OF MULTI-ROW SLIT SHEAR WALLS \\ USING LOW YIELD POINT STEEL
}

\section{Takuma TOGO*, Liusheng HE* ${ }^{*}$, Kazuhiro HAYASHI**, Masahiro KURATA*** and Masayoshi NAKASHIMA****}

\author{
* Graduate Student, Faculty of Engineering, Kyoto Univ. \\ ** Assistant Prof., Graduate School of Engineering, TUT, Dr. Eng. \\ * Assoc. Prof., DPRI, Kyoto Univ., Ph. D. \\ **** Prof., DPRI, Kyoto Univ., Ph. D.
}

The steel slit shear wall provides an effective lateral force resisting system, in which strength and stiffness can be designed flexibly by altering the length, interval and pattern of slits in a steel plate. Under shear deformation, the segment between slits (termed as "link") dissipates energy through the plasticity developed at link ends. In the perspective of achieving good energy dissipation capacity, two issues need to be considered: 1) strength degradation and pinched hysteresis and 2) occurrence of fracture at link ends. The strength degradation and pinched hysteresis can be avoided by careful design, for instance links can be designed small in the width-thickness ratio so that out-of-plane buckling in links can be restrained. However, the fracture at link ends, which may cause sharp strength degradation or even brittle failure, is closely related to material property. The limited material hardening associated with the commonly used conventional steel makes fracture occur soon after material yields. To eliminate or significantly reduce stress concentration and following fracture at link ends, this paper develops the slit shear wall made of low yield point steel (LY100). Besides the elimination of fracture, the extremely low yield stress of LY100 enables the energy dissipation to start at small drifts and its significant strain hardening allows for expansion of plasticity within the wall and thus better energy dissipation is expected.

Four 1/2.4-scaled slit walls were tested in the experimental validation, one with links in two rows made of conventional steel and the rest three made of LY100 with links in two, three and six rows respectively. Major findings from both the test and analysis are summarized as follows:

1) The equations used for the wall made of conventional steel in former researches could evaluate both initial stiffness and yield strength of those made of LY100 on the safe side. Same strength and stiffness were obtained in the three walls made of LY100 with different slit configurations, which demonstrated the flexibility in design of slit walls.

2) In the walls made of LY100, increment of strength due to the large strain hardening and formation of tension field at large drifts were confirmed in test.

3) Within the drift ratio of $1 \%$, shear deformation was evenly distributed at all links in the walls made of LY100, which dispersed the strain at slit ends and expanded plasticity in large regions. In the wall made of conventional steel, the shear deformation was unevenly distributed and the ratio between the two rows reached 2.4 at the drift ratio of $1 \%$.

4) By carefully designing the width-thickness ratio, stable hysteresis can be achieved without the need of out-of-plane constrainers. Among the three walls made of LY100, the one with links in two rows with the width-thickness ratio of 7.9 showed notable out-of-plane buckling in links after the drift ratio of 3.5\%, which resulted in somewhat pinched hysteresis. The other two with smaller width-thickness ratios, with links in three rows with the width-thickness ratio of 5.1 and links in six rows with the width-thickness ratio of 2.6, behaved mainly in-plane without notable out-of-plane buckling in links, which ensured sufficient development of plasticity and accordingly fat hysteresis loops.

5) The walls made of LY100 exhibited excellent ductility with no fracture observed till the completion of loading at the drift ratio of $4.5 \%$. While in the wall made of conventional steel, sharp strength degradation was observed after fracture occurred at slit ends at the drift ratio of $2 \%$ and eventually fracture penetrated the majority of links in the lower row at the drift ratio of $3 \%$. 